УДК 625.03

Канд. техн. наук О.М. Даренський

\title{
МАТЕМАТИЧНА МОДЕЛЬ ПРОСТІРОВИХ ЖОРСТКОСТЕЙ СКРІПЛЕННЯ ТИПУ ДО
}

\author{
Представив д-р техн. наук, професор В.І. Мороз
}

Вступ. Дослідження чисельними методами сил взаємодії спеціального i спеціалізованого рухомого складу на колію промислових залізниць дозволяють визначити як умови експлуатації існуючих конструкцій елементів верхньої будови колії, так і вихідні дані для проектування спеціальних конструкцій для особливих умов промтранспорту - високих осьових навантажень, наявності кривих з радіусами меншими, ніж 150 м, значними ухилами профілю (до 60 \%) та ін.

Для проведення таких досліджень особливе значення має створення математичних моделей роботи як колії в цілому, так і окремих іiі елементів. Чим точніше математична модель відображає роботу конструкції, тим ближче будуть отримані результати до реальних, визначених експериментально.

\begin{abstract}
Скріплення типу ДО $є$ найпоширенішим типом проміжного скріплення для конструкції ланкової колії на дерев'яних шпалах, протяжність якої перевищує $40 \%$ загальної протяжності колії промислового транспорту.

Аналіз останніх досліджень i публікацій. Для умов магістральних залізниць дослідження характеристик просторової пружності рейкових ниток при дерев'яних шпалах були проведені О.П. Ершковим [1]. Ці параметри були необхідні для практичного розв'язання задач про вигини і кручення рейки як балки на суцільній пружній основі [2]. Значний внесок у розвиток теоретичних уявлень про роботу суцільної підрейкової основи був зроблений Е.I. Даниленком, який сформулював основні положення концепції багатошарової підрейкової основи [3].
\end{abstract}


Проте для умов промислових залізниць, у яких загальна розрахункова схема колії як балки на суцільній пружній основі не завжди може бути використана [4], питання визначення просторових жорсткостей рейкових опор потребує подальших досліджень.

Основна частина. Вертикальна жорсткість скріплень ДО. При дії вертикального навантаження $R_{y}$ на скріплення ДО відбуваються, зминання i стиснення упоперек волокон деревини шпали під підкладкою. Приймаючи пружний опір деревини рівномірно розподіленим за площею підкладки (рис. 1), можна записати

$$
R_{y}=\omega_{n} \cdot q_{n o \partial},
$$

де $\omega_{n} \quad-$ площа підрейкової підкладки скріплення ДО, $\mu^{2}$;

$q_{\text {под }}-$ розподілений пружний опір древесини, $\kappa H / \mathrm{m}^{2}$.

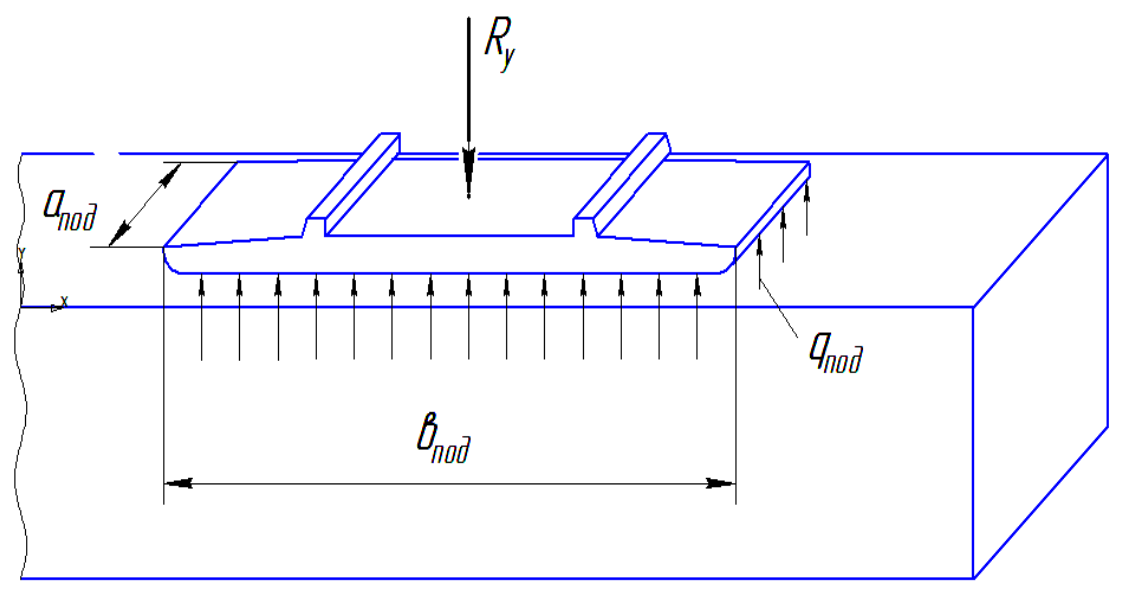

Рис. 1. Розрахункова схема для визначення вертикальної жорсткості скріплення ДО

Введемо розрахункову величину $C_{\text {под }}$ - коефіцієнт постелі підкладки, характеризуючу пружні властивості деревини при іiі зминанні і стисненні упоперек волокон і чисельно рівну навантаженню, яке прикладене до одиничної площі деревини і яке викличе одиночну пружну деформацію $\left(\kappa H / \mu^{3}\right)$.

Тоді

$$
q_{\text {nод }}=C_{\text {nод }} \cdot y_{c k p}^{c p},
$$

де $y_{\text {скр }}^{c p}$ - середнє значення вертикальної пружної деформації в скріпленні ДО, $м$.
Металева
підкладка
повинна розглядатися як пластина, що розташована на пружній основі і працює під дією

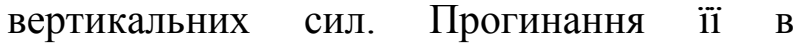
підрейковому перетині виявляються більшими, ніж це було б у разі жорсткого штампу. Проте при визначених пружних властивостях деревини не під штампом, а під металевою підкладкою скріплення в результаті експериментальних робіт можна отримати значення $C_{\text {nод }} 3$ урахуванням жорсткості підкладки.

$$
3 \text { урахуванням висловленого }
$$
вертикальну жорсткість скріплення ДО можна визначати як

$$
C_{y c \kappa}=\omega_{n} \cdot C_{n o d}
$$

де $\omega_{n}$ - площа підкладки, $M^{2}$. 
Горизонтальна поперечна жорсткість скріплення ДО. Розрахункова схема для визначення горизонтальної поперечної жорсткості наведена на рис. 2. Ця схема застосовна за таких умов: дія горизонтальної поперечної сили $R_{z}$ викликає тільки горизонтальне переміщення рейки без іiі кручення; між підошвою рейки, підкладкою і костилями зазори відсутні.

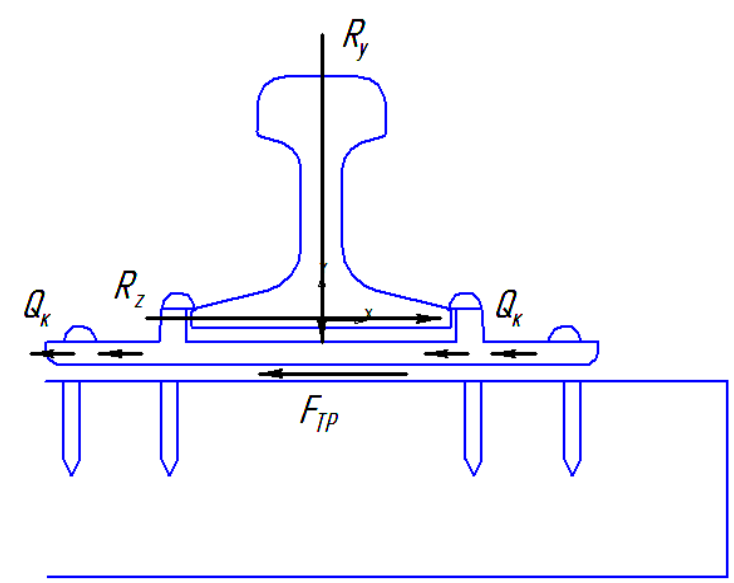

Рис. 2. Схема завантаження вузла скріплення ДО поперечним навантаженням

Умова рівноваги у вузлі скріплення має вигляд

$$
R_{z}=F_{m p}+m Q_{\kappa},
$$

де $F_{m p}$ - сила тертя підкладки по шпалі;

$Q_{\kappa}$ - опір одного костиля поперечному віджиманню;

$m$ - кількість основних і обшивальних костилів у вузлі скріплення.

До подолання сили тертя $F_{m p}$ горизонтальних поперечних деформацій у вузлі скріплення не відбувається.

Тоді умови прояву i формування горизонтальної поперечної жорсткості скріплення ДО можна подати як такі вирази:

$$
\left.\begin{array}{c}
-n p u R_{z}<f_{\text {nод }} \cdot R_{y} \\
C_{z}=\infty \\
-n p u R_{z} \geq f_{\text {nод }} \cdot R_{y} \\
C_{z}=m \cdot C_{\kappa}(\kappa H / \mathcal{M})
\end{array}\right\},
$$

де $R_{y}$ i $R_{z}$ - діючі на вузол скріплення вертикальна і горизонтальна поперечні сили, $\kappa H$;

$f_{\text {nод }}-$ коефіцієнт тертя підкладки по шпалі;

$C_{\kappa} \quad$ - жорсткість костиля при його поперечному віджиманні, $\kappa H / м$.

Жорсткість скріплення ДО при крученні рейки. Скріплення ДО працює на кручення, будучи одночасно завантаженим вертикальною силою $R_{y}$. Ця сила створює зминання i стиснення деревини на величину $y$, викликаючи пружний опір, інтенсивність якої можна подати у вигляді розподіленої по ширині підкладки $\boldsymbol{b}_{\text {nод }}$ реакції (рис. 1).

$$
q_{n}=\frac{R_{y}}{B_{n о \partial}}=\frac{\omega_{n} \cdot C_{n o \partial}}{B_{n о \partial}} \cdot y,
$$

де $\omega_{n}$ - площа підкладки, $\mu^{2}$;

$C_{\text {под }}$ - коефіцієнт постелі підкладки, $\kappa H / \mu^{3}$. 
Під дією крутного моменту $M_{\kappa p}$ додаткові деформації $\Delta y_{1}$ i $\Delta y_{2}$ (рис. 3). кромки підошви підкладки одержують

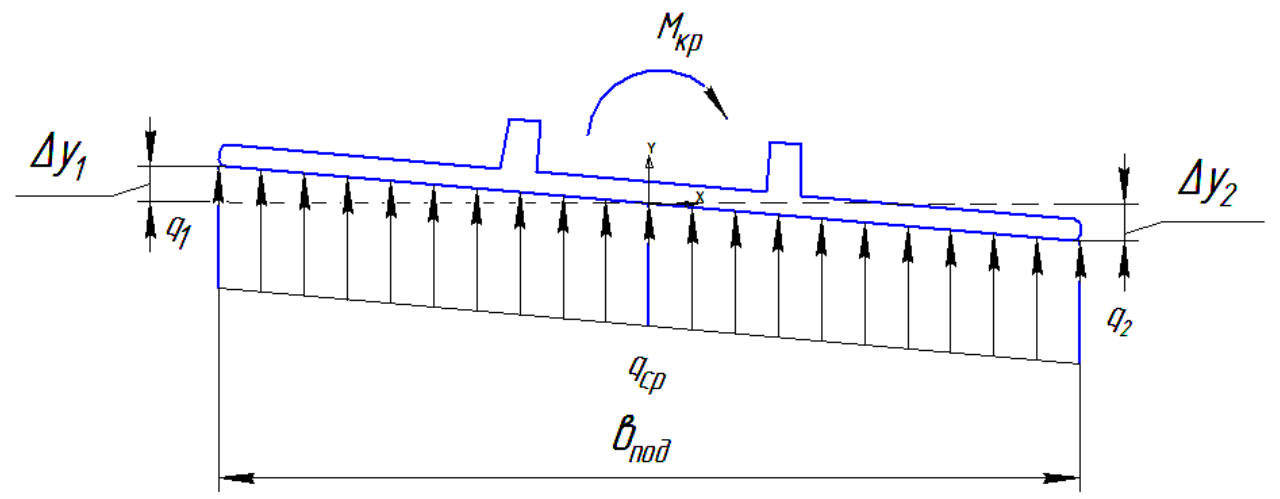

Рис. 3. Схема навантаження вузла скріплення ДО крутним моментом

При цьому величини $\Delta y_{1}$ i $\Delta y_{2}$ значно менше величини деформації $y_{1}$, викликаної вертикальним навантаженням $R_{y}$ [2]. Таким чином, розглядаючи умову рівноваги моментів у вузлі скріплення ДО, зміною сил притиснення основних $\mathrm{i}$ обшивальних костилів можна нехтувати.

Умова рівноваги зовнішнього крутного моменту $M_{\kappa p}$ i моменту нерівномірно розподіленої реакції деревини шпали відносно центра повороту перетину рейки матиме вигляд

$$
\grave{I}_{\hat{e} \delta}+\left(q_{1}+q_{\tilde{n} \delta}\right) \frac{\hat{a}_{\hat{\imath} \ddot{i}}^{2}}{16}-\left(q_{\tilde{n} \delta}+q_{2}\right) \frac{\hat{a}_{\hat{u} \ddot{u}}^{2}}{16}=0 .
$$

або

$$
M_{\kappa p}=\left(q_{2}-q_{1}\right) \frac{\boldsymbol{B}_{n o d}^{2}}{16}
$$

Інтенсивності розподіленого навантаження $q_{1}$ i $q_{2}$ :

$$
\begin{aligned}
& q_{1}=\left(o-\Delta o_{1}\right) \frac{\omega_{i \mathfrak{i}} \cdot \tilde{N}_{i \dddot{u} a}}{\hat{a}_{i \dddot{u} a}}, \\
& q_{2}=\left(y+\Delta y_{2}\right) \frac{\omega_{n} \cdot C_{n o \partial}}{B_{n o \partial}}
\end{aligned}
$$

Тоді вираз (3) матиме вигляд

$$
\grave{I}_{\hat{e} \circlearrowright}=\left(\frac{\Delta o_{2}+\Delta o_{1}}{\hat{a}_{\hat{i} \ddot{a}}}\right) \omega_{i} \cdot \tilde{N}_{i \grave{u} a} \frac{\hat{a}_{i \grave{a} a}^{2}}{16} .
$$

Враховуючи, що з причини малості кута закручування $\varphi=\frac{\Delta y_{2}+\Delta y_{1}}{\beta_{\text {nод }}}$, можна одержати залежність жорсткості скріплення ДО при крученні від коефіцієнта постелі підкладки у вигляді:

$$
C_{\varphi}=\omega_{n} \cdot C_{n o \partial} \cdot \frac{B_{n o \partial}^{2}}{16} .
$$

Висновок. Отримано розрахункові рівняння, які дозволяють визначити просторові жорсткості проміжних скріплень типу ДО $з$ урахуванням рівня діючих навантажень. Для отримання чисельних значень цих жорсткостей i ïx змін у процесі експлуатації колії необхідні значення коефіцієнтів постелі підкладки, опір i жорсткість костилів Ск при їх поперечному віджиманні. Ці параметри повинні бути визначені експериментально. 


\section{Список літератури}

1. Ершков, О.П. Характеристики пространственной упругости рельсовой нити [Текст] / О.П. Ершков // Труды ВНИИЖТ. - М.: Трансжелдориздат. - 1960. - № 192. - С. 59-101.

2. Ершков, О.П. Расчёт рельсов на действие боковых сил в кривых [Текст] / О.П. Ершков // Труды ВНИИЖТ. - М.: Трансжелдориздат. - 1960. - № 192. - С. 5-58.

3. Правила розрахунків залізничної колії на міцність та стійкість [Текст] / Е.І. Даніленко, В.В. Рибкін. - К.: Транспорт України, 2006. - 168 с.

4. Даренський, О.М. Методологічні основи вибору розрахункової схеми динамічної системи «екіпаж - рейкова колія» для умов промислового транспорту [Текст] / О.М. Даренський // Інформаційно-керуючі системи на залізничному транспорті. - 2010. №2. - С. 32-36. ДО.

Ключові слова: колії промислових залізниць, просторові жорсткості скріплення типу

\section{Анотації}

Розглянуто роботу проміжного скріплення типу ДО під дією вертикальних і горизонтальних поперечних сил. Отримано розрахункові рівняння, які дозволяють визначити вертикальну, горизонтальну поперечну жорсткість і жорсткість цього скріплення при крученні рейки.

Рассмотрена работа промежуточного скрепления типа ДО под действием вертикальных и горизонтальных поперечных сил. Получены расчетные уравнения, которые позволяют определить вертикальную, горизонтальную поперечную жесткости и жесткость этого скрепления при кручении рельса.

Considered Work intermediate bonding type ДО under vertical and horizontal transverse forces. The resulting design equations for determining vertical, horizontal lateral stiffness and torsional stiffness of the rail fastening. 